Playing for Keeps 
We are accustomed to think of play and seriousness as an absolute antithesis. It would seem, however, that this does not go to the heart of the matter.

—Johan Huizinga, Homo Ludens 


\section{Playing for Keeps}

A History of Early Baseball

\section{WARREN GOLDSTEIN}

2 OTH A N N IVERSARY E D T ION

Cornell University Press • Ithaca and London 


\section{Copyright $\odot 1989$ by Cornell University}

Preface and Selected Bibliography copyright $\left({ }_{0} 2009\right.$ by Cornell University

All rights reserved. Except for brief quotations in a review, this book, or parts thereof, must not be reproduced in any form without permission in writing from the publisher. For information, address Cornell University Press, Sage House, 5I2 East State Street, Ithaca, New York I4850.

First published 1989 by Cornell University Press

First printing, 2oth Anniversary Edition, 2009

Printed in the United States of America

\section{Library of Congress Cataloging-in-Publication Data}

Goldstein, Warren Jay.

Playing for keeps : a history of early baseball / Warren Goldstein.-20th anniversary ed.

p. $\mathrm{cm}$.

Includes bibliographical references and index.

ISBN 978-0-80I4-7508-5 (pbk. : alk. paper)

I. Baseball-United States-History-I9th century. I. Title.

$$
\begin{aligned}
& \text { GV863.AiG66 } 2009 \\
& \text { 796.357'0973-dc22 }
\end{aligned}
$$

2008049987

Cornell University Press strives to use environmentally responsible suppliers and materials to the fullest extent possible in the publishing of its books. Such materials include vegetable-based, low-VOC inks and acid-free papers that are recycled, totally chlorine-free, or partly composed of nonwood fibers. For further information, visit our website at www.cornellpress.cornell.edu.

$\begin{array}{lllllllllll}\text { Paperback printing } & \text { IO } & 9 & 8 & 7 & 6 & 5 & 4 & 3 & 2 & \text { I }\end{array}$ 
For Donna 
